\title{
Prolactin, prolactin receptor and uncoupling proteins during fetal and neonatal development
}

\author{
S. Pearce ${ }^{1 *}$, A. Mostyn ${ }^{1}$, M. C. Alves-Guerra ${ }^{2}$, C. Pecqueur ${ }^{2}$, B. Miroux ${ }^{2}$, R. Webb $^{3}$, \\ T. Stephenson ${ }^{1}$ and M. E. Symonds ${ }^{1}$ \\ ${ }^{1}$ Academic Division of Child Health, School of Human Development, University Hospital, Nottingham NG7 2UH, UK \\ ${ }^{2}$ CEREMOD, 9 rue Jules Hetzel, 92190 Meudon, France \\ ${ }^{3}$ Division of Agriculture and Horticulture, School of Biosciences, University of Nottingham, Sutton Bonington Campus, \\ Loughbrough LE12 5RD, UK
}

\begin{abstract}
Uncoupling proteins (UCP) 1 and 2 are members of the subfamily of inner mitochondrial membrane carriers. UCP1 is specific to brown adipose tissue (BAT), where it is responsible for the rapid production of heat at birth. In fetal sheep UCP1 is first detectable at approximately $90 \mathrm{~d}$ of gestation; its abundance increases with gestational age and peaks at the time of birth. The mRNA and protein for both the long and short form of the prolactin (PRL) receptor (PRLR) are also highly abundant in BAT. Enhanced PRLR abundance in late gestation is associated with an increase in the abundance of UCP1. This relationship between PRLR and UCP is not only present in BAT. Similar findings are now reported in the pregnant ovine uterus, where PRLR abundance reaches a maximum just before that of UCP2. However, the role of PRLR in BAT remains undetermined. Rat studies have shown that PRL administration throughout pregnancy results in offspring with increased UCP1 at birth. Studies in newborn lambs have shown that administration of PRL $(2 \mathrm{mg} / \mathrm{d})$ causes an acute response, increasing colonic temperature in the first hour by $1^{\circ}$. This increased colonic temperature is maintained for the first $24 \mathrm{~h}$ of life, in conjunction with enhanced lipolysis. After $7 \mathrm{~d}$ of treatment there is no difference in the abundance of UCP1 but an increase in UCP1 activity; this effect may be mediated by an increase in lipolysis. Taken together these findings suggest that PRL could be an important endocrine factor during pregnancy and early postnatal life.
\end{abstract}

Prolactin: Prolactin receptor: Uncoupling proteins: Fetal and neonatal development: Brown adipose tissue

The hormone prolactin (PRL) is secreted primarily from the anterior pituitary and is a member of the cytokine superfamily, which also includes growth hormone, placental lactogen and leptin. In most mammalian species PRL consists of 197-199 amino acids and has a molecular weight of $23 \mathrm{kDa}$ (Sinha, 1995; Goffin et al. 1999). The presence of PRL in the pituitary was established first by the French researchers Stricker and Grueter in the early 20th century, as a pituitary fraction capable of inducing lactation in rabbits (Goffin et al. 2002). 'PRL' was later named by Riddle, Bates and Dykshorn, a group of US researchers who made similar observations (Sinha, 1995; Bole-Feysot et al. 1998). PRL has been reported to be associated with numerous physiological functions (>300; Sinha, 1995; Goffin et al. 1999), including reproduction and the growth and differentiation of the mammary gland.

It was initially thought that PRL was synthesised and secreted exclusively by the lactotroph cells of the anterior pituitary. However, in recent years there has been an increase in the number of tissues in which PRL or PRL-like molecules have been reported to be present. These tissues include the placenta, uterus, myometrium, brain, immune system, mammary gland and adrenal gland (Ben-Jonathan et al. 1996).

The expression of PRL is controlled by dopamine negative feedback, although there are a number of other factors that are capable of both stimulating and inhibiting its synthesis and secretion (Gellersen et al. 1991). Pituitary PRL acts via the classic endocrine pathway. It is secreted by 
the pituitary gland and transported via the circulation to act on target cells via specific prolactin receptors (PRLR) located on the plasma membrane (Bole-Feysot et al. 1998). Locally produced PRL can act either on adjacent cells (paracrine) or on the PRL-secreting cell (autocrine). These methods of action allow PRL to be effective without always altering its circulating concentration (Bole-Feysot et al. 1998).

\section{Prolactin and fetal development}

PRL is present in the human fetal circulation from mid- to late gestation, which represents the period of maximal fetal tissue growth, organ maturation and nutrient storage. The human fetus expresses the PRLR in a diverse number of tissues from 7.5 weeks of gestation (Freemark, 2001). For the first 3 months of life human neonates have higher plasma PRL levels than adults (Gluckman et al. 1981). In preterm infants the PRL concentration in plasma sampled during the first $2 \mathrm{~d}$ of neonatal life is related to gestational age, with a marked increase in the PRL levels between 25 and 34 weeks of gestation (Lucas et al. 1990). The process of normal labour is also known to increase plasma PRL at birth, with babies born by Caesarean section having lower PRL levels than babies born vaginally (Heasman et al. 1997).

PRL is present in the fetal circulation of many species; until recently it was thought that the ovine fetus synthesised its own PRL, as it was unable to cross the placenta due to its large molecular weight (Gluckman et al. 1981; McMillen et al. 1983). However, in a recent study it was shown that when PRL is administered to rat dams throughout pregnancy, $60 \%$ of the fetal PRL is derived from the maternal blood (Yang et al. 2002). In rats the hypothalamus-pituitary axis develops postnatally, while in sheep, in which the axis matures before birth, fetal PRL synthesis and secretion are well regulated (Phillips et al. 1999). There is an increase in PRL and gene expression in both the circulation and the pituitary during the last $10-15 \mathrm{~d}$ of gestation in the sheep fetus (Gluckman et al. 1981; Merei et al. 1993; Phillips et al. 1996). These changes in circulating PRL are dependent on an intact hypothalamus (Phillips et al. 1996). This process coincides with tissue-specific increases in the abundance of the PRLR, of which there are two forms, long and short. The isoforms differ in the length and composition of their cytoplasmic tails (Bole-Feysot et al. 1998). mRNA for both forms of the receptor, long and short, have been found in the fetal perirenal adipose tissue during late gestation in the sheep fetus, with mRNA expression increasing between 90 and $125 \mathrm{~d}$ of gestation and declining before term (Symonds et al. 1998). The rise in PRLR mRNA in perirenal adipose tissue is observed before the increase in plasma cortisol or rises in any of the other circulating hormones, e.g. PRL or thyroid hormones (Symonds et al. 1998). The stage of gestation at which PRLR expression peaks in fetal adipose tissue coincides with the first appearance of brown adipose tissue (BAT)specific uncoupling protein (UCP) 1 (Fig. 1). It has been shown that the mRNA for the PRLR is then translated into protein for both forms of the PRLR in the fetal adipose tissue (Bispham et al. 1999). (a)

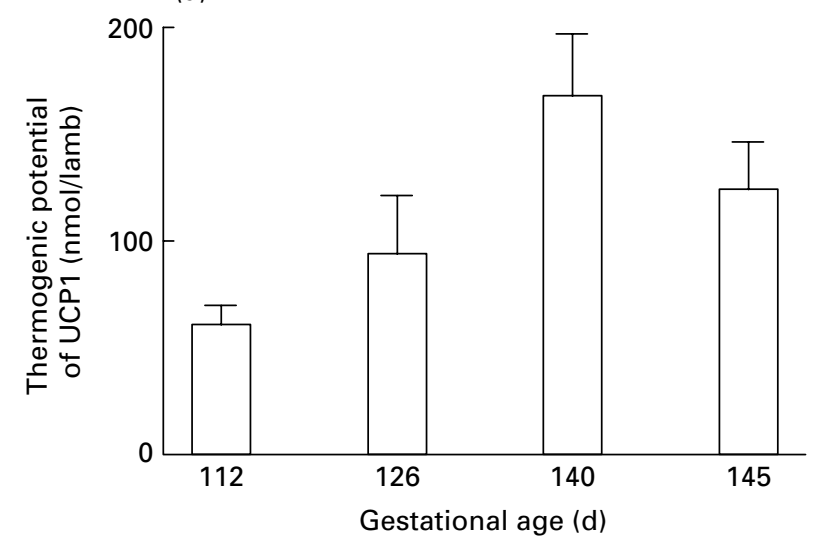

(b)

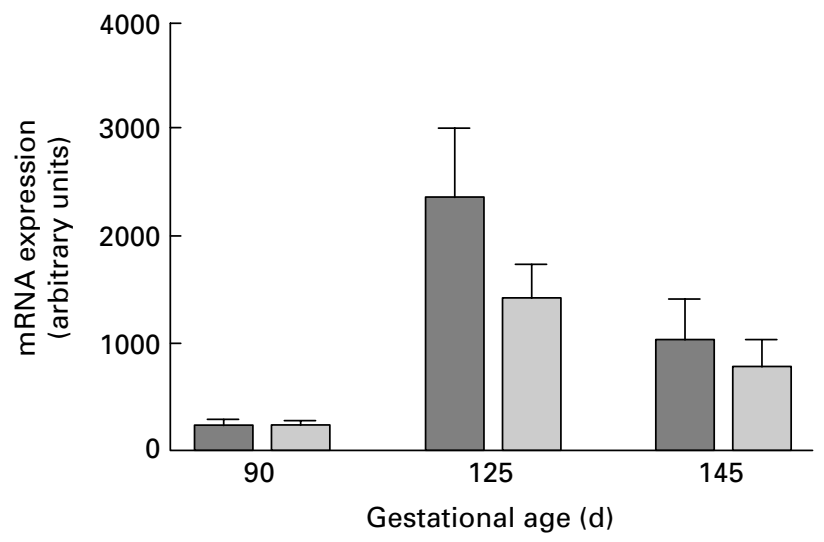

Fig. 1. Effect of gestational age on (a) the thermogenic potential of uncoupling protein (UCP) 1 (Symonds et al. 2001) and (b) prolactin

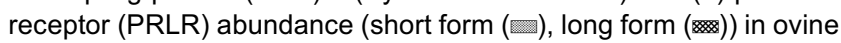
perirenal adipose tissue, as described by Symonds et al. (1998). Values are means with their standard errors represented by vertical bars.

\section{Brown adipose tissue and uncoupling protein 1}

BAT has been shown to be present in the majority of mammals studied to date (Klaus et al. 1991) and is the main source of non-shivering thermogenesis. In neonates of precocial species, including lambs and human infants, nonshivering thermogenesis and uncoupled oxidation within BAT mitochondria are crucial for heat production in the first few days of life (Cannon et al. 1988). In contrast, in altricial species, e.g. rats and mice, offspring huddle in a nest for the first few days of life and heat production by non-shivering thermogenesis becomes important only when the young emerge from the nest (Cannon et al. 1988). Depending on species, BAT is highly abundant and well developed at birth, when the main stimulus for non-shivering thermogenesis is the steep decline in temperature at parturition (Clarke et al. 1997c). BAT is present throughout neonatal and adult life in rodents, where it can be activated by cold exposure (i.e. for cold-induced thermogenesis), by diet-induced thermogenesis (e.g. by a cafeteria diet; Gemmel et al. 1972; Ricquier \& Bouillaud, 2000b) and 
during emergence from hibernation (Ricquier \& Bouillaud, $2000 a$ ). BAT is found in characteristic depots around the body, with the main areas being interscapular, axillar, perirenal, thoracic and between the neck muscles (Ricquier $\&$ Bouillaud, 2000b). In fetal and neonatal lambs $80 \%$ of the BAT is found surrounding the kidney, and is therefore termed perirenal adipose tissue.

BAT is unique in its ability to produce large amounts of heat and is the only tissue in the mammalian body dedicated to this role (Nedergaard \& Cannon, 1992). The neonatal sheep can produce on average $350-500 \mathrm{~W}$ heat $/ \mathrm{kg}$ BAT (Nicholls \& Locke, 1983) compared with $1-3 \mathrm{~W} / \mathrm{kg}$ in other tissues (Power, 1989). BAT is specialised for its role in heat production in a number of ways. It has a high extent of vascularisation, which is important for transporting $\mathrm{O}_{2}$ to the tissue and allowing the heat produced to be effectively distributed around the body. It also possesses a large store of triacylglycerol droplets, which can be used as a fuel to produce immediate heat when necessary (Cannon et al. 1988). The other important specialisation of BAT is the presence of a large number of mitochondria that are filled with many cristae (Gemmel et al. 1972).

BAT is unique in being able to produce large amounts of heat rapidly, due to the presence on its inner mitochondrial membrane of the protein UCP1, or thermogenin, which can produce heat as a result of the uncoupling of ATP oxidation. Protons generated from the respiratory chain return to the matrix of the mitochondria through UCP1, thus producing heat (Lowell, 1998; Fig. 2). Activation of UCP1 is highly regulated so that heat is only produced under specific conditions, when necessary. The overall capacity of BAT to produce heat is dependent on the amount of UCP1 present in the tissue and its thermogenic potential.

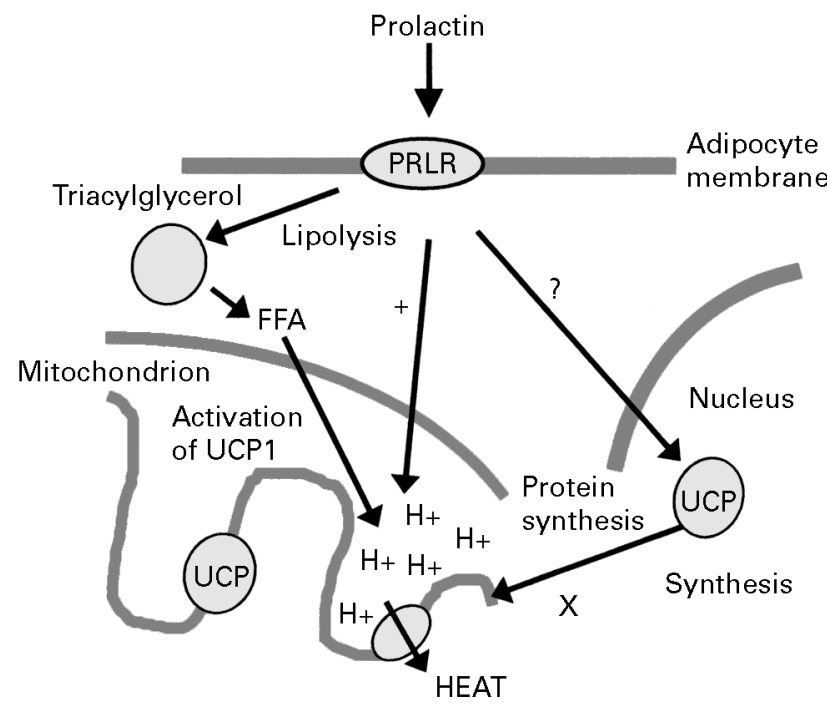

Fig. 2. Schematic diagram showing possible interaction between prolactin and its receptor (PRLR) to increase uncoupling protein (UCP) 1 activity. FFA, non-esterified fatty acids; +, promotion of hydrogen ions across the inner mitochondrial membrane via UCP1; $X$, prolactin is not increasing the synthesis of UCP1 protein from UCP1 mRNA.
BAT is present in the perirenal region of the sheep fetus from $70 \mathrm{~d}$ of gestation and increases relative to body weight until day 110 . Sympathetic innervation is present at $130 \mathrm{~d}$ of gestation and increases until term (day 147 in the sheep; Symonds et al. 2001). UCP1 is present in the mitochondria of BAT of human infants and lambs. In lambs UCP1 is present from the beginning of the third trimester and peaks around the time of birth (Casteilla et al. 1987; Lean, 1989; Clarke et al. 1997a). The activity of UCP1 also increases with gestational age and reaches a maximum just after birth (Clarke et al. 1997c).

From birth to $30 \mathrm{~d}$ postnatally in sheep perirenal adipose tissue develops further in two distinct phases, representing the change from BAT to white adipose tissue. The first phase occurs between birth and up to 1 week of age. During this phase high quantities of UCP1 mRNA are maintained, with a peak in the activity of UCP1 occurring at about day 4 (Clarke et al. 1997b). It is also during this phase that both plasma leptin protein and mRNA increase to a maximum at day 7 of postnatal life (Bispham et al. 2002). In the second phase of this development, between days 7 and 30, there is an increase in both the weight and lipid content of the adipose tissue; this change coincides with complete loss of both UCP1 mRNA and protein (Clarke et al. 1997b). It has been suggested that these phases of development of BAT could be directly linked to changes in body temperature (Clarke et al. 1997b).

\section{Prolactin receptor and uncoupling protein 2 in the pregnant uterus}

PRL is thought to be responsible in part for maintaining a constant environment for embryo and fetal development. PRLR-knockout models result in implantation failure and fetal loss in early pregnancy; however, successful pregnancy can be achieved with additional progesterone, suggesting an association between pregnancy and PRLR (Reese et al. 2000). PRLR mRNA has been shown to be localised in the ovine endometrium during pregnancy and to increase with gestation (Cassy et al. 1999). The function of uterine PRLR is unknown; however, it is thought to be vital for the maintenance of pregnancy in late gestation (Reese et al. 2000). UCP2 mRNA is expressed in the uterus of rodents (Fleury et al. 1997; Masaki et al. 1999); its expression increases from mid-gestation, reaching a maximum level in late gestation (Masaki et al. 1999). UCP2 is a mitochondrial protein of the same family as UCP1 and was identified more recently than UCP1 (Fleury et al. 1997; Gimeo et al. 1997). Unlike UCP1, which is specific to BAT, UCP2 is expressed in a variety of tissues, e.g. ovine brain, spleen, lung, liver and white adipose tissue (Mostyn, 2001). At present, the role of UCP2 is uncertain; it is thought to be involved in lipid metabolism, resting metabolism and the regulation of reactive oxygen species (Fleury \& Sanchis, 1999; Arsenijevic et al. 2000).

In view of the temporal association between UCP1 and PRLR in BAT, it was decided to investigate the relative abundance of PRLR and UCP2 protein in the ovine uterus from mid- $(85 \mathrm{~d})$ to late $(135 \mathrm{~d})$ gestation. An increase in both the long and the short forms of PRLR was found between 85 and $99 \mathrm{~d}$ of gestation, and at $99 \mathrm{~d}$ abundance was 
(a)

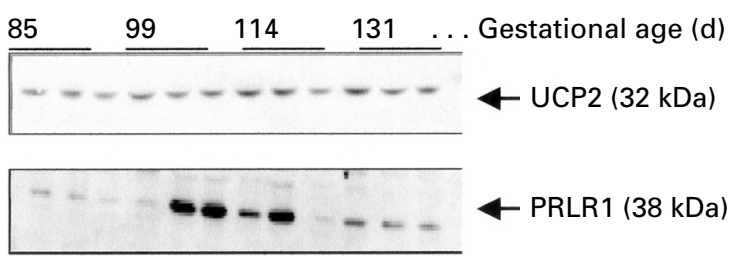

(b)

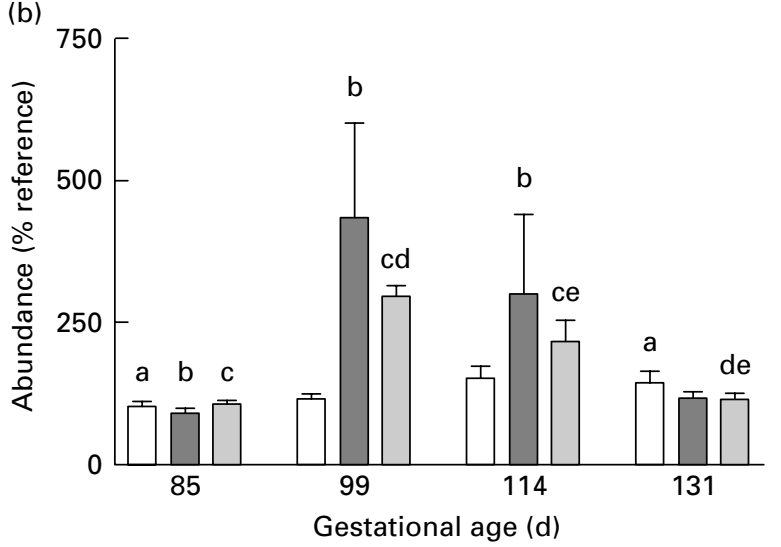

Fig. 3. Ontogeny of the abundance of uncoupling protein (UCP) 2 and the long ( $38 \mathrm{kDa}$ isoform) and short ( $29 \mathrm{kDa}$ isoform) forms of the prolactin receptor (PRLR1 and 2 respectively) in the pregnant ovine uterus as described by Pearce et al. (2003). (a) Western blots for UCP2 and PLRL1 at the gestational ages shown. (b) Abundance of UCP2 $(\square)$ and PRLR $1(\square)$ and 2 ( $\$ x)$. Values are means with their

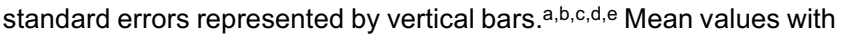
the same superscript letter were significantly different $(P<0.05)$.

maximal. In addition, UCP2 abundance increased with gestation to reach a maximum at $114 \mathrm{~d}$ of gestation (Pearce et al. 2003; Fig. 3). This relationship in the pregnant uterus is similar to that reported between PRLR and UCP1 in BAT (Fig. 1) and may implicate PRL as a 'permissive' factor in the induction of UCP expression.

\section{Nutritional and endocrine regulation of fetal adipose tissue development}

A number of factors, including fetal number and maternal nutrition during pregnancy, have been shown to alter the abundance of PRLR and UCP1 in the neonatal lamb. The deposition of fetal adipose tissue decreases with fetal number (Alexander, 1978; Budge et al. 2003) and following maternal nutrient restriction in late gestation (Budge et al. 2003). Twins sampled during late gestation and at birth have significantly less $(P<0.05)$ perirenal adipose tissue than singletons at the same gestational age (Alexander, 1978; Budge et al. 2003), and this finding correlates with singletons having higher colonic temperatures than multiple births. Twins also showed an increase in the abundance of the short form of the PRLR compared with singletons (Budge et al. 2002a). Being a twin may also have an effect on the nutrition experienced whilst in utero; twin fetuses have lower plasma glucose levels than singletons (Symonds et al. 2000).
Increased nutrition during the second half of gestation (from day 80 to day 140) has been shown to increase plasma PRL levels (Symonds et al. 2001) and lamb weight. These heavier lambs had less adipose tissue with a higher abundance of UCP1 and increased activity compared with the control lambs (Budge et al. 2000).

In sheep models in which nutritional or placental restriction have been investigated differential effects have been observed. In near-term fetuses from placentallyrestricted ewes, in which both $\mathrm{O}_{2}$ and nutrient supply were limited, there was an increase in UCP1 mRNA expression. However, in fetuses from nutrient-restricted ewes, in which intake was restricted to $50 \%$ from $115 \mathrm{~d}$ of gestation, there was a decrease in the expression of UCP1 (Budge et al. 2002a). Maternal plasma PRL concentrations were reduced in ewes when they were nutrient restricted in the last third of pregnancy, while fetal plasma PRL concentrations remained unaltered (Koritnik et al. 1981).

\section{Effect of prolactin on uncoupling protein 1 in the neonatal and fetal rat}

Although PRLR is expressed in BAT its role remains to be established. It was shown recently that when pregnant rats are infused with PRL throughout gestation there is a reduction in the number of visible lipid droplets at birth (Yang et al. 2001) and an increase in the abundance of UCP1 (Budge et al. 2002b). PRL appears to increase thermogenic activity in pups and this increase is associated with an increase in the plasma leptin levels (Budge et al. $2002 b$ ). However, in lactating rat dams the opposite effect is observed, with an increase in circulating PRL levels being associated with a decrease in UCP1 (Chan \& Swaminathan, 1990). In non-lactating adult rats PRL administration stimulates leptin secretion (Gualillo et al. 1999), which may further act to increase UCP1 expression (Scarpace et al. 1997). When PRL was administered to rats at 15, 35 and $60 \mathrm{~d}$ of age, however, a decrease in UCP1 abundance was observed after $35 \mathrm{~d}$ (Pearce et al. 2001). Both leptin and PRL-releasing peptide have recently been shown to increase core body temperature in rodents when administered individually, with a greater effect seen when they were administered together (Ellacott et al. 2002). These findings suggest that the effects of PRL on thermogenesis in rodents are dependent on both age and gender. Taken together these findings suggest that PRLR could be an important factor in the regulation of UCP abundance during pregnancy and in later life.

\section{Effect of chronic prolactin treatment to neonatal lambs}

In order to determine whether PRL can promote thermoregulation in the newborn, a study was carried out in which its effect on thermogenesis over the first $7 \mathrm{~d}$ of postnatal life was investigated. Weight-matched 1-d-old triplet lambs were included in the study and randomly assigned to treatment with PRL (2 mg ovine PRL/d) or a vehicle. Colonic temperature and blood samples were taken daily before treatment. Perirenal adipose tissue samples were taken on day 7 for immunoblotting analysis using an ovinespecific UCP1 antibody (Schermer et al. 1996). 


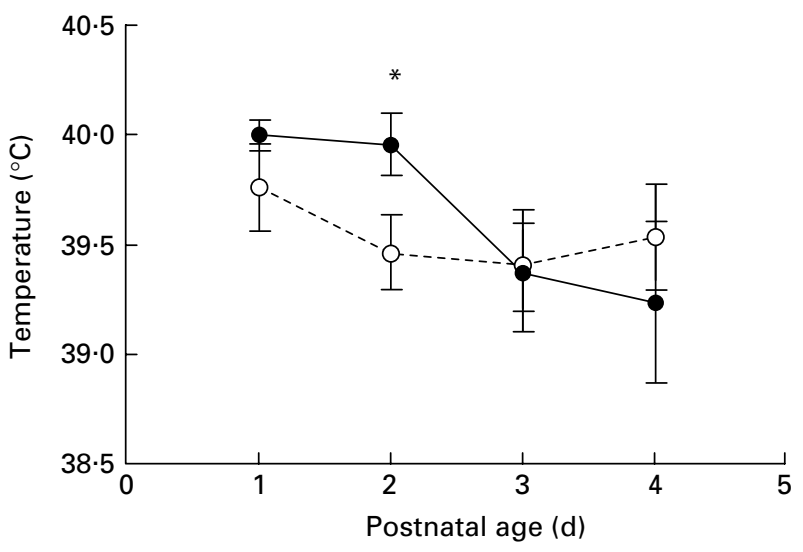

Fig. 4. The effect of chronic prolactin (PRL) treatment $(2 \mathrm{mg} / \mathrm{ml}$ per d) on colonic temperature in pairs of 1-d-old lambs treated daily with either prolactin $(-\bullet)$ or vehicle $(0--O)$ for the first week of postnatal life. Values are means with their standard errors represented by vertical bars. Mean values for PRL-treated lambs were significantly higher than those for the controls: ${ }^{*} P<0.05$. (From Pearce et al. 2000.)

This dose of PRL was sufficient to increase plasma PRL levels fivefold (Stephenson et al. 2001), a level similar to those observed during long days (Bassett et al. 1989). There was no difference in lamb body weight between the PRLand vehicle-treated groups during the study (Pearce $e t$ al. 2000). There is a natural decline in lamb colonic temperature over the first $2 \mathrm{~d}$ of postnatal life, which is followed by an increase up to day 7 , reaching a level that is maintained once independent feeding is established (Clarke et al. 1997b). The PRL-treated lambs did not exhibit this normal decline in colonic temperature between days 1 and 2 of postnatal life, and therefore had a significantly higher $(P<0.05)$ colonic temperature on day 2 (Pearce et al. 2000; Fig. 4). There was no difference in the UCP1 abundance between groups, but PRL-treated lambs had BAT with a greater thermogenic potential than the controls (Genever et al. 2001). This effect may be mediated by an increase in non-esterified fatty acids since they activate UCP1 by unmasking the guanosine diphosphate-binding site (Cannon $\&$ Nedergaard, 1985), thereby increasing the amount of heat produced. Fetal sheep have low plasma non-esterified fatty acid concentrations. However, within the first few hours after birth non-esterified fatty acids are rapidly mobilised from triacylglycerol stores, and by day 2 these levels decline (Noble et al. 1971).

\section{Effect of acute prolactin treatment on neonatal lambs}

In order to determine the acute physiological and molecular changes that occur immediately before the colonic temperature was increased by PRL, a more detailed investigation was undertaken using 1-d-old lambs. Colonic temperature and blood samples were taken from each lamb before and during PRL administration ( $2 \mathrm{mg}$ ovine PRL) and up to 120 min post treatment.

PRL-treated lambs exhibited a significant $(P<0.05)$ increase in colonic temperature, which peaked at $40 \mathrm{~min}$ (a)

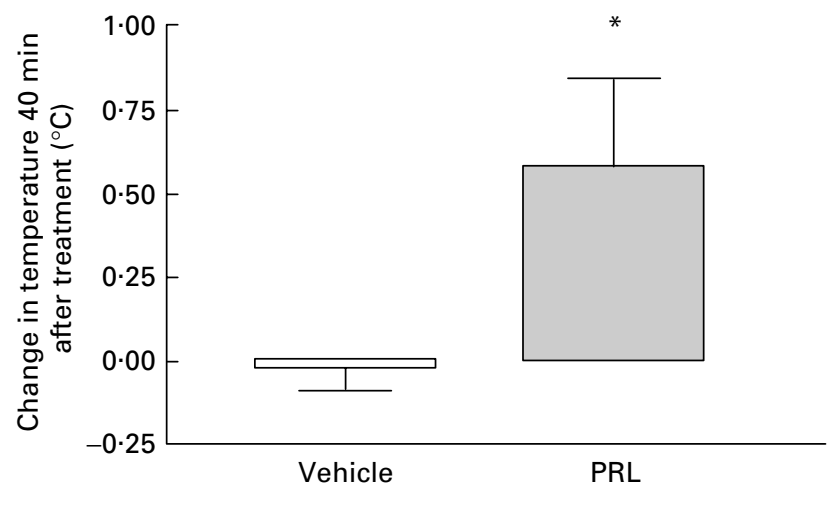

(b)

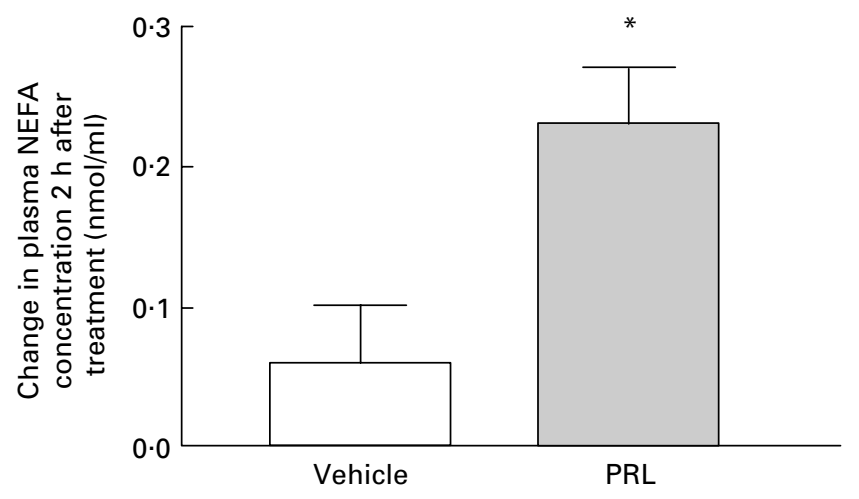

Fig. 5. The effect of acute prolactin (PRL) treatment $(2 \mathrm{mg} / \mathrm{ml})$ on (a) colonic temperature $40 \mathrm{~min}$ after treatment and (b) plasma non-esterified fatty acid (NEFA) concentrations $2 \mathrm{~h}$ after treatment in pairs of 1-d-old lambs treated on day 1 of postnatal life with either PRL (ख) or vehicle $(\square)$. Values are means with their standard errors represented by vertical bars. Mean values for PRL-treated lambs were significantly higher than those for the controls: ${ }^{*} P<0.05$.

post administration (Fig. 5(a)). This response was not associated with any change in the abundance of UCP1, but there was a marked increase in the plasma non-esterified fatty acid concentration (Fig. 5(b)). These effects were observed in the absence of any visible shivering, suggesting that the response is likely to be due to non-shivering thermogenesis in the BAT.

\section{Conclusion}

The positive relationship between PRLR abundance and UCP during development in BAT and in the pregnant uterus suggests that PRLR may be important in regulating increases in UCP abundance in these tissues. PRL administered to pregnant rats and neonatal lambs results in an increase in UCP1 or improved thermoregulation, an effect that is mediated in part by an increase in lipolysis. Future research aimed at further understanding this action of PRL has the potential to improve the health and viability of infants and lambs. 


\section{Acknowledgements}

S.P. was supported by a BBSRC studentship and A.M. by a University of Nottingham Postgraduate Scholarship.

\section{References}

Alexander G (1978) Quantitative development of adipose tissue in foetal sheep. Australian Journal of Biological Science 31, 489-503.

Arsenijevic D, Onuma H, Pecqueur C, Raimbault S, Manning BS, Miroux B, Couplan E, Alves-Guerra M-C, Goubern M, Surwit R, Bouillaud F, Richard D, Collins S \& Ricquier D (2000) Disruption of the uncoupling protein-2 gene in mice reveals a role in immunity and reactive oxygen species production. Nature Genetics 26, 435-439.

Bassett JM, Curtis N, Hanson C \& Weeding CM (1989) Effects of altered photoperiod or maternal melatonin administration on plasma prolactin concentrations in fetal lambs. Journal of Endocrinology 122, 633-643.

Ben-Jonathan N, Mershon JL, Allen DL \& Steinmetz RW (1996) Extra pituitary prolactin: distribution, regulation, functions, and clinical aspects. Endocrine Reviews 17, 639-669.

Bispham J, Budge H, Mostyn A, Dandrea J, Clarke L, Keisler D, Symonds ME \& Stephenson T (2002) Ambient temperature, maternal dexamethasone, and postnatal ontogeny of leptin in the neonatal lamb. Pediatric Research 52, 85-90.

Bispham J, Heasman L, Clarke L, Ingleton PM, Stephenson T \& Symonds ME (1999) Effect of maternal dexamethasone treatment and ambient temperature on prolactin receptor abundance in brown adipose and hepatic tissue in the foetal and new-born lamb. Journal of Neuroendocrinology 11, 849-856.

Bole-Feysot C, Goffin V, Edery M, Binart N \& Kelly PA (1998) Prolactin (PRL) and its receptor: actions, signal transduction pathways and phenotypes observed in prolactin receptor knockout mice. Endocrine Reviews 19, 225-268.

Budge H, Bispham J, Dandrea J, Evans E, Heasman L, Ingleton PM, Sullivan C, Wilson V, Stephenson T \& Symonds ME (2000) Effect of maternal nutrition on brown adipose tissue and its prolactin receptor status in the fetal lamb. Pediatric Research $\mathbf{4 7}$, 781-786.

Budge H, Bryce A, Owens JA, Stephenson T, Symonds ME \& McMillen IC (2002a) Differential effects of nutrient restriction in late gestation and placental restriction throughout gestation on uncoupling protein 1 expression in fetal perinatal adipose tissue. Early Human Development 66, 43.

Budge H, Dandrea J, Mostyn A, Evens Y, Watkins R, Sullivan C, Ingleton P, Stephenson T \& Symonds ME (2003) Differential effects of fetal number and maternal nutrition in late gestation on prolactin receptor abundance and adipose tissue development in the neonatal lamb. Pediatric Research 53, 302-308.

Budge H, Mostyn A, Wilson V, Khong A, Walker AM, Symonds ME \& Stephenson T (2002b) The effect of maternal prolactin infusion during pregnancy on fetal adipose tissue development. Journal of Endocrinology 174, 427-433.

Cannon B, Connoley E, Obregon M-J \& Nedergaard J (1988) Perinatal activation of brown adipose tissue. In The Endocrine Control of the Fetus, pp. 306-320 [W Kunzel and A Jesen, editors]. Berlin: Springer Verlag.

Cannon B \& Nedergaard J (1985) The biochemistry of an inefficient tissue: brown adipose tissue. Essays in Biochemistry 20, 110-164.

Cassy S, Charlier M, Guillomot M, Pessemesse L \& Dijane J (1999) Cellular localization and evolution of prolactin receptor mRNA in ovine endometrium during pregnancy. FEBS Letters $\mathbf{4 4 5}$, 207-211.
Casteilla L, Forest C, Robelin J, Ricquier D, Lombet A \& Ailhaud G (1987) Characterization of mitochondrial-uncoupling protein in bovine fetus and newborn calf. American Journal of Physiology 15, E627-E636.

Chan E \& Swaminathan R (1990) Role of prolactin in lactationinduced changes in brown adipose tissue. American Journal of Physiology 27, R51-R56.

Clarke L, Bryant MJ, Lomax MA \& Symonds ME (1997a) Maternal manipulation of brown adipose tissue and liver development in the ovine fetus during late gestation. British Journal of Nutrition 77, 871-883.

Clarke L, Buss DS, Juniper DT, Lomax MA \& Symonds ME (1997b) Adipose tissue development during early postnatal life in ewe-reared lambs. Experimental Physiology 82, 1015-1027.

Clarke L, Heasman L, Firth K \& Symonds ME (1997c) Influence of route of delivery and ambient temperature on thermoregulation in newborn lambs. American Journal of Physiology 272, R1931-R1939.

Ellacott KLJ, Lawrence CB, Rothwell NJ \& Luckman SM (2002) PRL-releasing peptide interacts with leptin to reduce food intake and body weight. Endocrinology 143, 368-374.

Fleury C, Neverova M, Collins S, Raimbault S, Champigny O, Levi-Meyrueis C, Bouillaud F, Seldin M, Surwit R, Ricquier D \& Warden C (1997) Uncoupling protein-2: a novel gene linked to obesity and hyperinsulinemia. Nature Genetics 15, 269-272.

Fleury C \& Sanchis D (1999) The mitochondrial uncoupling protein-2: current status. International Journal of Biochemistry and Cell Biology 31, 1261-1278.

Freemark M (2001) Ontogenesis of prolactin receptors in the human fetus: roles in fetal development. Biochemical Society Transactions 29, 38-41.

Gellersen B, Bonhoff A, Hunt N \& Bohnet H (1991) Decidual-type prolactin expression by the human myometrium. Endocrinology 129, 158-168.

Gemmel RT, Bell AW \& Alexander G (1972) Morphology of adipose cells in lambs at birth and during subsequent transition of brown to white adipose tissue in cold and warm conditions. American Journal of Anatomy 133, 143-164.

Genever E, Ingleton PM, Mostyn A, Pearce S, Stephenson T, Symonds ME \& Webb R (2001) Effect of administration of prolactin on thermoregulation in neonatal lambs. Proceedings of the Physiological Society of New Zealand 20, P932.

Gimeo R, Dembski M, Weng X, Deng N, Shyjan A, Gimeno C, Iris F, Ellis S, Woolf E \& Tartaglia L (1997) Cloning and characterization of an uncoupling protein homolog: a potential molecular mediator of human thermogenesis. Diabetes 46, 900-906.

Gluckman PD, Grumbach MM \& Kaplan SL (1981) The neuroendocrine regulation and function of growth hormone and prolactin in the mammalian fetus. Endocrine Reviews 2, 363-395.

Goffin V, Binart N, Clement-Lacroix P, Bouchard B, Bole-Feysot C, Edery M, Lucas BK, Touraine P, Pezet A, Maaskant R, Pichard C, Helloco C, Baran N, Favre H, Bernichtein S, Allamando A, Ormandy C \& Kelly PA (1999) From the molecular biology of prolactin and its receptor to the lessons learned from knockout mice models. Genetic Analysis: Biomolecular Engineering 15, 189-201.

Goffin V, Binart N, Touraine P \& Kelly P (2002) Prolactin: The new biology of an old hormone. Annual Review of Physiology 64, 47-67.

Gualillo O, Lago F, Garcia M, Menendez C, Senaris R, Casanueva FF \& Dieguez C (1999) Prolactin stimulates leptin secretion by rat white adipose tissue. Endocrinology 140, 5149-5153.

Heasman L, Spencer JAD \& Symonds ME (1997) Plasma prolactin concentrations after Caesarean section or vaginal delivery. Archives of Diseases in Childhood 77, 237-238. 
Klaus S, Casteilla L, Bouillaud F \& Ricquier D (1991) The uncoupling protein UCP: a membraneous mitochondrial ion carrier exclusively expressed in brown adipose tissue. International Journal of Biochemistry 23, 791-801.

Koritnik DR, Humphrey WD, Kaltenbach CC \& Dunn TG (1981) Effects of maternal undernutrition on the development of the ovine fetus and the associated changes in growth hormone and prolactin. Biology of Reproduction 24, 125-137.

Lean M (1989) Brown adipose tissue in humans. Proceedings of the Nutrition Society 48, 243-256.

Lowell BB (1998) Adaptive thermogenesis: Turning on the heat. Current Biology 8, R517-R520.

Lucas A, Baker BA \& Cole TJ (1990) Plasma prolactin and clinical outcome in preterm infants. Archives of Diseases in Childhood 65, 977-983.

McMillen IC, Jenkin G, Thorburn G \& Robinson J (1983) Concentrations of prolactin in the plasma of the fetal sheep and in amniotic fluid in late gestation and during dexamethasone induced parturition. Journal of Endocrinology 99, 107-114.

Masaki T, Yoshimata H, Chiba S, Kurokawa M \& Sakata T (1999) Up-regulation of uterine UCP2 and UCP3 in pregnant rats. Biochimica et Biophysica Acta 1440, 81-88.

Merei J, Rao A, Clarke I \& McMillen I (1993) Proopiomelanocortin, prolactin and growth hormone messenger ribonucleic acid levels in the fetal sheep pituitary during late gestation. Acta Endocrinologica 129, 263-267.

Mostyn A (2001) Endocrine regulation of adipose tissue thermogenesis in the fetal and neonatal sheep. PhD Thesis, Nottingham University.

Nedergaard J \& Cannon B (1992) The uncoupling protein thermogenin and mitochondrial thermogenesis. New Comprehensive Biochemistry 23, 385-419.

Nicholls DG \& Locke RM (1983) Cellular mechanisms of heat dissipation. In Mammalian Thermogenesis, pp. 8-49 [L Girardier and M Stock, editors]. New York: Chapman and Hall.

Noble RC, Steele W \& Moore JH (1971) Diet and the fatty acids in the plasma of lambs during the first eight days after birth. Lipids 1, 26-34.

Pearce S, Alves-Guerra M-C, Pecqueur C, Miroux B, Symonds ME \& Stephenson T (2003) Ontogeny of prolactin receptor and uncoupling protein 2 in the pregnant uterus during mid to late gestation in sheep. Early Human Development (In the Press).

Pearce S, Dieguez C, Symonds ME \& Stephenson T (2001) The effect of chronic prolactin administration to growing rats on uncoupling protein (UCP)-1 abundance in intrascapular brown adipose tissue (BAT). Endocrine Abstracts 2, P54.

Pearce S, Genever E, Mostyn A, Webb R, Ingleton PM, Symonds ME \& Stephenson T (2000) Effect of administration of prolactin on thermoregulation in neonatal lambs. Early Human Development 60, 49-50.

Phillips ID, Anthony RV, Houghton DC \& McMillen IC (1999) The regulation of prolactin receptor messenger ribonucleic acid levels in the sheep liver before birth: relative roles of the fetal hypothalamus, cortisol, and external photoperiod. Endocrinology 140, 1966-1971.

Phillips ID, Fielke SI, Young IR \& McMillen IC (1996) The relative roles of the hypothalamus and cortisol in the control of prolactin gene expression in the anterior pituitary of the sheep fetus. Journal of Neuroendocrinology 8, 929-933.

Power G (1989) Biology of temperature: the mammalian fetus. Journal of Developmental Physiology 12, 295-304.

Reese J, Binart N, Brown N, Ma W-G, Paria BC, Das SK, Kelly PA \& Dey SK (2000) Implication and decidualization defects in prolactin receptor (PRLR)-deficient mice are mediated by ovarian but not uterine PRLR. Endocrinology 141, 1872-1881.

Ricquier D \& Bouillaud F (2000a) Mitochondrial uncoupling proteins: from mitochondria to the regulation of energy balance. Journal of Physiology 529, 3-10.

Ricquier D \& Bouillaud F (2000b) The uncoupling protein homologues: UCP1, UCP2, UCP3, StUCP and AtUCP. Biochemical Journal 345, 161-179.

Scarpace P, Matheny M, Pollock B \& Tumer N (1997) Leptin increases uncoupling protein expression and energy expenditure. American Journal of Physiology 273, E226-E230.

Schermer S, Bird JA, Lomax MA, Shepherd D \& Symonds ME (1996) Effect of fetal thyroidectomy on brown adipose tissue thermoregulation in newborn lambs. Reproduction, Fertility and Development 8, 995-1002.

Sinha YN (1995) Structural variants of prolactin: occurrence and physiological significance. Endocrine Reviews 16, 354-369.

Stephenson T, Budge H, Mostyn A, Pearce S, Webb R \& Symonds ME (2001) Fetal and neonatal adipose maturation: a primary site of cytokine and cytokine-receptor action. Biochemical Society Transactions 29, 80-85.

Symonds ME, Budge H \& Stephenson T (2000) Limitations of models used to examine the influence of nutrition during pregnancy and adult disease. Archives of Diseases in Childhood 83, 215-219.

Symonds ME, Mostyn A \& Stephenson T (2001) Cytokines and cytokine receptors in fetal growth and development. Biochemical Society Transactions 29, 33-37.

Symonds ME, Phillips ID, Anthony RV, Owens JA \& McMillen IC (1998) Prolactin receptor gene expression and foetal adipose tissue. Journal of Neuroendocrinology 10, 885-890.

Yang L, Kuo CB, Liu Y, Coss D, Xu X, Chen C, Oster-Granite ML \& Walker AM (2001) Administration of unmodified prolactin (U-PRL) and a molecular mimic of phosphorylated prolactin (PP-PRL) during rat pregnancy provides evidence that the U-PRL:PP-PRL ratio is crucial to the normal development of pup tissue. Journal of Endocrinology $\mathbf{1 6 8}$, 227-238.

Yang L, Lii S, Kuo B, Buckley A, Buckley D, Chen C, Xu X, Coss D \& Walker AM (2002) Maternal prolactin composition can permanently affect epidermal $\gamma \delta \mathrm{T}$ cell function in the offspring. Developmental and Comparative Immunology 26, $849-860$ 